\title{
Effect of ozonation on the Staphylococcus Aureus innoculated in milk
}

\section{Efeito da ozonização sobre a contagem da Staphylococcus Aureus inoculado em leite}

\author{
Emanuel Pereira Couto ${ }^{1 *}$; Ernandes Rodrigues Alencar ${ }^{2}$; \\ Vítor Salvador Picão Gonçalves ${ }^{3}$; Anderson Joaquim Pereira dos Santos ${ }^{1}$; \\ Jaqueline Lamounier Ribeiro ${ }^{4}$; Márcia de Aguiar Ferreira ${ }^{5}$
}

\begin{abstract}
The aim of this research was evaluate the efficiency of the action of ozonation of milk on the reduction of the bacterial counts of Staphylococcus aureus artificially inoculated and subjected to different binomials times/concentrations of ozone. The samples were divided in four assays: 1 and 2, with skim milk and ozone concentrations of $34.7 \mathrm{mg} \mathrm{L}^{-1}$ and $44.8 \mathrm{mg} \mathrm{L}^{-1}$, respectively, and assays 3 and 4, with whole milk and the same concentrations of ozone. The time of ozonation in all of the assays was 5 (T1), 10 (T2), 15 (T3), 20 (T4) and 25 (T5) minutes. Each treatment was replicated three times. The bacterial counts were determined immediately before and after the ozonation process by plating the samples on Baird Parker agar. In treatments 1 and 2 , the greatest reductions were $0.42 \log _{10} \mathrm{CFU} / \mathrm{mL}$ (colony forming units per millilitre), whereas in treatments 3 and 4 , the greatest reductions were 0.19 and $0.21 \log _{10} \mathrm{CFU} / \mathrm{mL}$, respectively. The results of all of the tests show that, for $\mathrm{T} 1$, there was no reduction in the microbial load, whereas for T2, there was a sharp decrease in the microbiota, and this decrease was even more significant for T4 and T5. In both skim and whole milk with ozone concentrations of 34.7 and $44.8 \mathrm{mg}$ $\mathrm{L}^{-1}$, the reductions were significantly greater after 20 minutes of ozonation. The results indicated that ozone showed low efficacy in the reduction of S.aureus inoculated into fluid milk and milk fat interferes with the bactericidal action of the gas.
\end{abstract}

Key words: Ozone. Staphylococcus aureus. Milk. Milk processing.

\section{Resumo}

O objetivo dessa pesquisa foi avaliar a eficiência do ozônio sobre a redução da contagem de Staphylococcus aureus artificialmente inoculados em leite, utilizando-se diferentes binômios tempo/ concentração. Foram realizados quatro ensaios: 1 e 2, com leite desnatado e concentrações de 34,7

1 Discentes, do Curso de Mestrado do Curso de Pós-Graduação em Ciências Animais, Laboratório de Análises de Leite e Derivados, Universidade de Brasília, UnB, Campus Universitário Darcy Ribeiro, Brasília, DF, Brasil. E-mail: emanupc@gmail. com; andersonjpsantos@gmail.com

2 Prof. Adjunto, Coordenador de Curso de Pós-Graduação em Agronomia, FAV/UnNB, Campus Universitário Darcy Ribeiro, Brasília, DF, Brasil. E-mail: ernandesalencar@unb.br

3 Prof. Adjunto, EPIPLAN, Laboratório de Epidemiologia Veterinária, FAV/UnNB, Campus Universitário Darcy Ribeiro, Brasília, DF, Brasil. E-mail: vitorspg@unb.br

4 Técnica Administrativa, Laboratório de Análises de Leite e Derivados, UNnB, Campus Universitário Darcy Ribeiro, Brasília, DF, Brasil. E-mail: jaqueribeiro@unb.br

5 Prof Adjunta, Faculdade de Agronomia e Veterinária doa Laboratório de Análises de Leite e Derivados, FAV/UNnB, Campus Universitário Darcy Ribeiro, Brasília, DF, Brasil. E-mail: mafer@unb.br

Author for correspondence 
$\mathrm{mg} \mathrm{L}^{-1}$ e 44,8 $\mathrm{mg} \mathrm{L}^{-1}$ de ozônio, respectivamente; e ensaios 3 e 4, com leite integral nas mesmas concentrações de ozônio. Os tempos de ozonização em todos os ensaios foram de 5 (T1), 10 (T2), 15 (T3), 20 (T4) e 25 (T5) minutos, sendo cada tratamento realizado em triplicata. As contagens bacterianas foram feitas imediatamente antes e após o processo de ozonização das amostras, em agar Baird Parker. Nos tratamentos 1 e 2, as maiores reduções foram de $0,42 \log _{10} \mathrm{UFC} / \mathrm{mL}$, enquanto nos tratamentos 3 e 4 , foram de 0,19 e $0,21 \log _{10} \mathrm{UFC} / \mathrm{mL}$, respectivamente. Os resultados de todos os ensaios mostraram que, em T1, não houve redução da carga microbiana, enquanto que a partir de T2, ocorreu uma redução crescente nas contagens, que foi acentuada nos tempos T4 e T5. Tanto para leite desnatado quanto para integral, nas concentrações de 34,7 e $44,8 \mathrm{mg} \mathrm{L}^{-1}$, a partir dos 20 minutos de ozonização, as reduções foram significativamente maiores. Os resultados indicaram que o ozônio apresentou baixa eficácia na redução de $S$. aureus inoculado em leite fluido e que a gordura do leite interfere na ação bactericida do gás.

Palavras-chave: Ozônio. Staphylococcus aureus. Leite. Beneficiamento do leite.

Milk is one of the most consumed foods in the world, and its consumption has grown in recent decades, especially in some developing countries, due to the increased access of the population to proteins of animal origin. One of the major reasons stimulating the consumption of milk is its unique nutritional characteristics due to the presence of more than a thousand different types of molecules with specific functions, and the possibility of industrial processing, which results in a wide range of products for commercialisation. In addition to being a food of great nutritional value, milk presents physico-chemical characteristics, such as $\mathrm{pH}$ and water activity, that make it a good culture medium for a wide variety of microorganisms, including pathogenic and spoilage microorganisms.

Among foodborne pathogens, the microorganism Staphylococcus aureus is especially important and has been responsible for several outbreaks of poisoning caused by staphylococcal enterotoxins, which are superantigens that are able to withstand the heat treatment of foods. Thus, this species has become important in dairy farming because it is one of the most prevalent species in mastitis cases related to herd management. Oliveira et al. (2013) have reported the presence of enterotoxigenic strains of $S$. aureus in milk from the farm to the production and commerce of dairy products in Brazil.

Ozone gas, the molecular triatomic form of oxygen, has been widely researched and used in the food industry, both for surface cleaning and for the treatment of raw material, because it is considered a chemical GRAS (Generally Recognised as Safe) by the FDA (Food and Drug Administration). Ozone has a master bactericidal effect in both Gram positive and Gram negative, due to its high oxidation potential $(2.07 \mathrm{mV})$, which is supported in the literature (KIM, 1998; PIRANI, 2011; SILVA, 2011). Among the various studies, it is important to highlight the results obtained from fruits, meat and meat products, as well as fish and their derivatives (POHLMAN, 2012; TIWARI and MUTHUKUMARAPPAN, 2012).

Although research on the use of ozone gas as an alternative method of treating food has advanced, there is a lack of studies evaluating the efficacy of this method in fluid milk and milk derivatives. Therefore, considering the importance of milk, this study aimed to evaluate the effect of ozonation on the reduction of $S$. aureus inoculated into fluid milk with different fat contents.

The study was conducted in the Laboratory of Milk and Dairy Products Analysis and the Laboratory of Pre-Processing and Storage of Agricultural Products, which are located in the Faculty of Agronomy and Veterinary, University of Brasília, Brazil.

Ultra-high-temperature (UHT) milk- whole and skim - was used for inoculum preparation with a $S$. aureus (ATCC 25923) strain, which was provided courtesy of the Laboratory of Veterinary Microbiology at the University of Brasilia. The 
strain was kept stocked in TSA (Tryptone Soya Agar - Himedia $\left.{ }^{\circledR}\right)$ agar. Fresh culture was prepared for each experimental replicate. Samples of milk were previously sterilised by boiling to ensure the complete elimination of any other microorganism. The inoculum was prepared in $0.85 \%$ saline solution to obtain a degree of turbidity corresponding to tube 1 of the nephelometric McFarland standards (Nefelobac ${ }^{\circledR}$, Probac Brazil), which is equivalent to approximately $3.0 \times 10^{8} \mathrm{CFU} / \mathrm{mL}$ of $S$. aureus. To obtain an approximate concentration of $3.0 \times 10^{4}$ $\mathrm{CFU} / \mathrm{mL}$ of $S$. aureus, a portion was transferred into $300-\mathrm{mL}$ aliquots and the concentration of cells was confirmed by plate count $\left(\mathrm{T}_{0}\right)$ of milk previously. The samples were kept refrigerated at an average temperature of $10^{\circ} \mathrm{C}\left(8^{\circ} \mathrm{C}-12^{\circ} \mathrm{C}\right)$ for the ozonation procedure.

The ozone gas was obtained from an ozone generator (O \& G Model-O2 3.0 RM \& Ozone ${ }^{\circledR}$ LIFE) based on the method of dielectric barrier discharge. This type of discharge is produced by applying a high voltage between two parallel electrodes with a dielectric between them (glass) and a free space through which the dry air flows. In the free space, a discharge is produced in the form of filaments, in which electrons with enough energy initiate the breakdown of oxygen molecules to form ozone $\left(\mathrm{O}_{3}\right)$. For the generation of ozone process, the input oxygen $\left(\mathrm{O}_{2}\right)$ was obtained from an oxygen concentrator coupled to the ozone generator.

The ozone concentration was determined by the iodometric method described by Clesceri et al. (2000). This method consists of bubbling ozone gas in $50 \mathrm{~mL}$ of a solution of $1 \mathrm{~N}$ potassium iodide (KI) with the production of iodine $\left(\mathrm{I}_{2}\right)$. To ensure the displacement reaction for the production of $\mathrm{I}_{2}$, it was necessary to acidify the solution with $2.5 \mathrm{ml}$ of $1 \mathrm{~N}$ sulphuric acid $\left(\mathrm{H}_{2} \mathrm{SO}_{4}\right)$ after bubbling. The solution was titrated with $0.01 \mathrm{~N}$ sodium thiosulfate $\left(\mathrm{Na}_{2} \mathrm{~S}_{2} \mathrm{O}_{3}\right)$ using $1 \%$ starch solution as a colour indicator.

Each milk sample was transferred to a glass column with a capacity of $500 \mathrm{~mL}$ (19-cm in height and $6 \mathrm{~cm}$ in diameter). Before this transfer, the column was sanitised by bubbling ozone gas in water for 5 minutes. The glass columns were connected to the ozone generator unit through silicone hoses. Furthermore, the residual ozone was destroyed after passing through a thermal catalytic device to keep the environmental air free of ozone. Thereby, 4 assays were established, with 5 variations of time $(5,10,15,20$ and 25 minutes $)$ and two ozone concentrations ( 34.7 and $44.8 \mathrm{mg} \mathrm{L}^{-1}$ ), as shown below (table 1). Each assay was performed in three times replications with whole milk (content $\geq 3.0 \%$ fat) and skim milk (content $\leq 0.6 \%$ fat).

Table 1. Presentation of the assays with the respective concentrations of ozone and time (T) of application.

\begin{tabular}{llll}
\hline Skim milk $(\leq 0,6 \%$ fat $)$ & & Whole milk $(\geq 3,0 \%$ fat $)$ & \\
\hline $\begin{array}{l}\text { Assay } 1 \\
\text { concentration }\end{array}$ & Assay 2 & Assay 3 & Assay 4 \\
$34.7 \mathrm{mg} / \mathrm{L}$ & concentration & concentration & concentration \\
\hline $\mathrm{T} 1=5$ minutes & $44.8 \mathrm{mg} / \mathrm{L}$ & $34.7 \mathrm{mg} / \mathrm{L}$ & $\mathrm{T} 1=5 \mathrm{minutes}$ \\
$\mathrm{T} 2=10$ minutes & $\mathrm{T} 1=5$ minutes & $\mathrm{T} 1=5$ minutes & $\mathrm{T} 2=10$ minutes \\
$\mathrm{T} 3=15$ minutes & $\mathrm{T} 2=10$ minutes & $\mathrm{T} 2=10$ minutes & $\mathrm{T} 3=15$ minutes \\
$\mathrm{T} 4=20$ minutes & $\mathrm{T} 3=15$ minutes & $\mathrm{T} 3=15$ minutes & $\mathrm{T} 4=20$ minutes \\
$\mathrm{T} 5=25$ minutes & $\mathrm{T} 4=20$ minutes & $\mathrm{T} 4=20$ minutes & $\mathrm{T} 5=25$ minutes \\
\hline
\end{tabular}


The samples were plated using Baird Parker agar (Acumedia ${ }^{\circledR}$ ), with $0,1 \mathrm{~mL}$ surface plating, and incubated at $35^{\circ} \mathrm{C}$ for $24 \mathrm{~h}$. All of the samples were plated in duplicate.

The residual concentration of the gas was determined after passing through the product in 5 -minute intervals for a period of up to 25 minutes. To relate the residual ozone gas concentration to the time, the data were adjusted to a sigmoidal equation (Equation 1):

$$
\mathrm{C}=\left[\frac{\mathrm{a}}{1+\mathrm{e}^{-(\mathrm{t}-\mathrm{b}) / \mathrm{c}}}\right]
$$

where $\mathrm{C}=$ concentration of the ozone gas $\left(\mathrm{mg} \mathrm{L}^{-1}\right)$; $\mathrm{t}=$ time ( $\mathrm{min})$; and $\mathrm{a}, \mathrm{b}$ and $\mathrm{c}$ are constants of the equation.

From the values of the constants $\mathrm{b}$ and $\mathrm{c}$, it is possible to obtain the saturation time (Equation 2) and subsequently the saturation concentration $\left(\mathrm{C}^{\mathrm{Sat}}\right)$, according to Venegas et al. (1998).

Equation 2, time of saturation (minutes):

$$
\mathrm{t}_{\text {Sat }}=\mathrm{b}+2 \mathrm{c}
$$

Knowing the value of CSat, it is possible to obtain the ratio $\mathrm{CSat} / \mathrm{C} 0$, where $\mathrm{C} 0$ is the initial concentration of ozone.

The results were analysed using the STATA $®$ 13 software after the logarithmic transformation of the data $\left(\log _{10} \mathrm{CFU} / \mathrm{mL}\right)$. To compare the means of each time within each assay, analysis of variance was performed (PAGANO; GAUVREAU, 2004), and to compare the means of the times between the different assays, Student's t test was performed (PAGANO; GAUVREAU, 2004).

Figure 1 shows the average variation related to the three replicates of the counts $\left(\log _{10} \mathrm{CFU} / \mathrm{ml}\right)$ of $S$. aureus for each time in each assay. In assays with skim milk (1 and 2), the highest reduction was 0.42 $\log _{10} \mathrm{CFU} / \mathrm{mL}$ at T5 (25 minutes), whereas in the tests with whole milk (3 and 4), the highest reductions were 0.19 and $0.21 \log _{10} \mathrm{CFU} / \mathrm{mL}$, respectively, at T5. The effect follows a consistent pattern in all assays. The results show that there is no reduction in microbial load for T1 (5 minutes), but starting with T2 (10 minutes), there is a steady decrease in the count of $S$. aureus with increasing treatment time. Thus, the effectiveness of the ozonation process in reducing the population of $S$. aureus is dependent on the time during which the ozone gas remains in contact with the microorganism.

Figure 1. Average variation of the counts of Staphylococcus aureus $\left(\log _{10} \mathrm{CFU} / \mathrm{mL}\right)$ after ozonation at each time for each test.

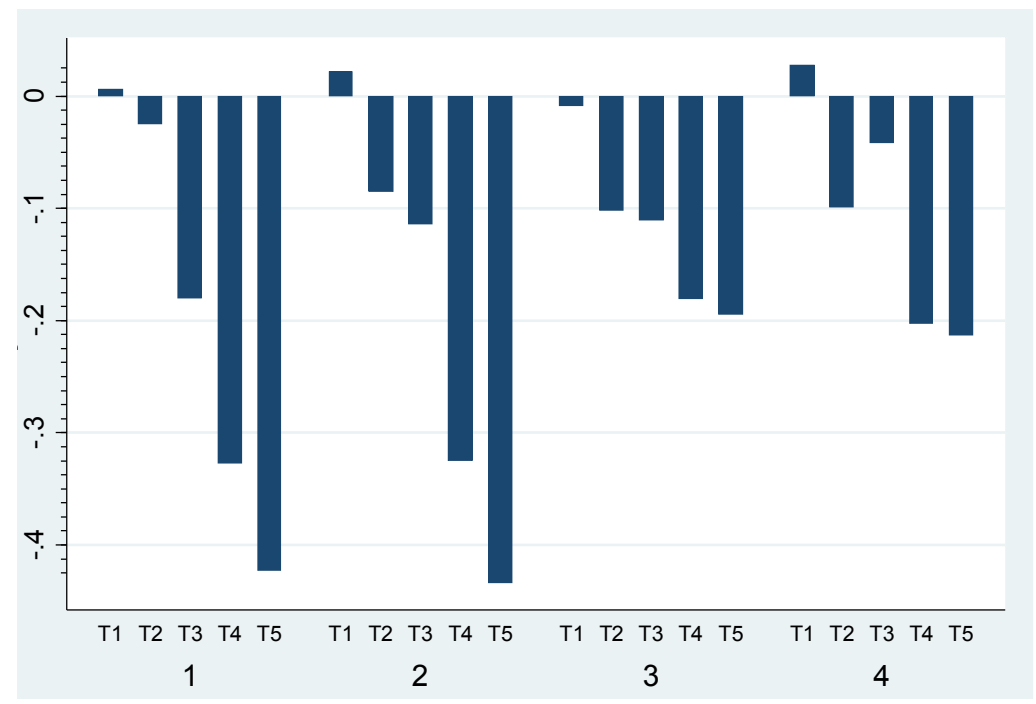


Some studies corroborate the effect of ozonation time on the bacterial counts of different species. Cavalcante et al. (2013) evaluated the effects of the ozonation of raw milk for 5, 10 and 15 minutes on its microflora (initial concentration of $1.5 \mathrm{mg} / \mathrm{L}$ ) and observed a $0.52 \log _{10} \mathrm{CFU} / \mathrm{mL}$ reduction in the population of Staphylococcus spp. after 10 minutes and a $1.02 \log _{10} \mathrm{CFU} / \mathrm{mL}$ reduction after 15 minutes. The work of Cavalcante et al. (2013), however, had some methodological differences to the present study, especially with respect to the use of the surfactant polysorbate 80 , which was used to improve contact with ozone and may have led to a greater reduction in the bacterial population. Sheelamary and Muthukumar (2011) verified the effectiveness of the ozonation of Listeria monocytogenes in milk and found that a reduction of half of the initial population after 5 minutes and the elimination of all microorganisms after 15 minutes of treatment. L. monocytogenes, according to the study of Restaino et al. (1995), is naturally more sensitive to ozone than $S$. aureus. Pirani (2011) evaluated the effects of ozone on colonies of $S$. aureus inserted in a controlled environment and noted that one hour of treatment resulted in a reduction of $3.1 \log _{10} \mathrm{CFU} /$ $\mathrm{mL}$. Similarly, this research also shows the need for a long contact time between molecular ozone and the colonies of $S$. aureus. During the same period of ozonation, there was a reduction of $5.8 \log _{10} \mathrm{CFU} /$ $\mathrm{mL}$ in the counts of Escherichia coli.

According to Silva et al. (2011), Gram-negative bacteria are, in general, more sensitive to ozone than Gram-positive bacteria due to the smaller amount of peptidoglycan in their cell walls, as was also observed by Kim (1998), who detected major damage to the cell structure of Gramnegative bacteria by electron microscopy. The peptidoglycan polymer is the main component of the cell wall of Gram-positive bacteria and contains $\mathrm{N}$-acetylglucosamine molecules. According to Rey et al. (1995), the $\mathrm{N}$-acetylglucosamine molecule is much more resistant to the action of ozone in an aqueous medium compared to the glucosamine molecule, which can explain part of the resistance to ozone of Gram-positive bacteria, particularly $S$. aureus, which has a relatively high amount $(50 \%$ by mass) of peptidoglycan in its cell wall.

Regarding the levels of ozone concentration used in the study $(34.7$ and $44.8 \mathrm{mg} / \mathrm{L})$ there was no significant difference $(\mathrm{P}>0.05)$ between the assay results. Therefore, under the conditions used in this work, an increase in the ozone concentration did not increase the efficiency of the process. On the other hand, Hunt and Mariñas (1997) studied the kinetics of the inactivation of $E$. coli by ozone and concluded that the concentration and the density of the active microorganisms were the main determinant factors of the efficiency of the process.

Silva et al. (2011) emphasised that the appropriate control of the concentration of ozone for the treatment of foods is important not only for its effectiveness but also to prevent oxidative damage, unpleasant odour and colour change. The concentrations used $(34.7 \mathrm{mg} / \mathrm{L}$ and $44.8 \mathrm{mg} / \mathrm{L})$ were selected taking into account the results obtained by Santos (2013), who performed the ozonation of raw milk samples using different times and different concentrations and achieved better efficiency with concentrations greater than $15 \mathrm{mg} / \mathrm{L}$.

The comparison of the results obtained from different milks (whole and skim) showed no significant differences $(\mathrm{P}<0.05)$ in the reduction of the microflora with treatment up to 15 minutes (T3); however, starting at 20 minutes (T4), there was a significant difference $(\mathrm{P}<0.05)$. The milk fat, even in homogenised (UHT) milk, interfered with the bactericidal action of ozone on $S$. aureus. Guzel-Seydim et al. (2004) evaluated the effects of ozonation on Bacillus stearothermophilus, E. coli and $S$. aureus inoculated on five different substrates: sterile buffer solution, whipping cream, a solution of locust bean gum, soluble starch solution and a solution of caseinate sodium. The authors concluded that the cream and caseinate promoted a greater protective effect in the bacteria. The reduction of 
S. aureus in starch was complete after 10 minutes, whereas in whipping cream, the reduction was only $1.02 \log _{10}$.

Patil et al. (2009) verified the effect of organic matter on the oxidative effect of ozone on E. coli in different orange juices (varying the amount of organic matter). The authors concluded that the organic matter interfered with the activity of ozone, which was more efficient when used on filtered juice. In water, the oxidation reactions of bacterial components by ozone can occur in two ways: direct oxidation by molecular ozone and indirect oxidation by free radicals formed through autodecomposition or reaction with organic or inorganic compounds (HUNT; MARINAS, 1997). The organic matter tends to interact with ozone before interfering with the oxidation of bacteria by direct contact with molecular ozone, which is the predominant mechanism. Moreover, according to Kim (1998), the amount of organic matter can also interfere with the solubility of ozone in liquid media.

Therefore, not only the presence of organic matter but also the type of matter can hinder the activity of ozone. Two aspects are emphasised: the saturation point of ozone gas and the concentrations of saturation with the respective values of CSat/ $\mathrm{C} 0$. The saturation time remained between 5.44 and 7.68 minutes. The saturation concentrations with the adopted initial concentration of $34.7 \mathrm{mg} / \mathrm{L}$ were equivalent to $19.69 \mathrm{mg} / \mathrm{L}(\mathrm{CSat} / \mathrm{C} 0=0.57)$ for skim milk and $13.39 \mathrm{mg} / \mathrm{L}(\mathrm{CSat} / \mathrm{C} 0=0.39)$ for whole milk. With an initial concentration of $44.8 \mathrm{mg} / \mathrm{L}$, the saturation concentrations were equivalent to 34.35 $(\mathrm{CSat} / \mathrm{C} 0=0.77)$ for skim milk and $30.86 \mathrm{mg} / \mathrm{L}$ $(\mathrm{CSat} / \mathrm{C} 0=0.69)$ for whole milk. Hence, when whole milk was used, the saturation concentration and the $\mathrm{CSat} / \mathrm{C} 0$ ratio were lower. This tendency may be associated with the more rapid degradation of ozone in the milk because the fat content is higher, which probably interfered with the efficiency of the ozonation process in the inactivation of $S$. aureus.
We emphasize the need for evaluation of the effect of ozonation on milk quality. During the ozonation, were noted, for example, changes in milk color as the concentration and time exposure to the gas were increased. It is important that this trend to be confirmed, also analyzing other physicochemical parameters such as contents of fat, protein and lactose.

The fat content in whole milk, even after homogenisation, decreases the efficiency of ozone for the reduction of $S$. aureus. The difference between the assays with whole and skim milk is significant after 20 minutes, when the treatment effect is more pronounced.

The results obtained in this study support the conclusion that ozone is not an effective method for the reduction of $S$. aureus in fluid milk if compared to other existing methods. However, its use in the food industry as a microbiological contamination control method cannot berejected. It is capable of causing reduction of the counts of $S$. aureus inoculated in whole milk and skim milk, and this reduction starts after 10 minutes of ozonation for both tested ozone concentrations. Moreover, the effects were more pronounced after 20 minutes of ozonation in all of the assays.

Studies are necessary that aim to increase the efficiency of the ozonation process milk in inactivating $S$. aureus and other microorganisms.

\section{References}

CAVALCANTE, M. A. Improvement of the raw milk microbiological quality by ozone treatment. International Food Research Journal, Selangor, v. 20, n. 4, p. 20172021, 2013.

CLESCERI, L. S.; GREENBERG, A. E.; EATON, A. D. Standard methods for the examination of water and wastewater. Denver: American Water Works Association, 2000. 1220 p.

GUZEL-SEYDIM, Z.; BEVER, P. I.; GREENE, A. K. Efficacy of ozone to reduce bacterial populations in the presence of food components. Food Microbiology, Clemson, v. 4, n. 21, p. 475-479, 2004. 
HUNT, N. K.; MARIÑAS, B. J. Kinetics of Escherichia coli inactivation with ozone. Water Research, Indiana, v. 31, n. 6, p. 1355-1362, 2007.

KIM, J. G. Ozone as an antimicrobial agent in minimally processed foods. 1998. Theis (Doctor and Food Science and Nutrition) - Ohio State University, Columbus.

OLIVEIRA, C. A. F. Ocorrência de Staphylococcus aureus no leite e ambiente de ordenha em propriedades leiteiras do estado de São Paulo. Veterinária e Zootecnia, v. 20, n. 2, p. 34-35, 2013. Suplemento 1.

PAGANO, M.; GAUVREAU, K. Princípios de bioestatística. Tradução da segunda edição norte americana. São Paulo: Pioneira Thomson Learning, 2004. 524 p.

PATIL, S., BOURKE, P., FRIAS, J., TIWARI, B., CULLEN, P. J. Inactivation of Escherichia coli in orange juice using ozone. Innovative Food Science and Emerging Technologies, Dublin, v. 10, n. 4, p. 551-557, 2009.

PIRANI, S. Application of ozone in food industries. 2011. Theis (Doctor and Animal Nutrition and Food Safety) Università degli Studi di Milano, Milão.

POHLMAN, F. W. Ozone in meat processing. In: O'DONNELL, C. P., TIWARI, B. K., CULLEN, P. J, RICE, R. G. Ozone in food processing. Oxford: Blackwell Publishing, 2012. p. 123-133.
RESTAINO, L.; FRAMPTOM, E. W.; HEMPHILL, J. B.; PALNIKAR, P. Efficacy of ozonated water against various food-related microorganisms. Applied and Environmental Microbiology, Washingon, v. 61, n. 9, p. 3471-3475, 1995.

REY, R. P.; SELLÉS, A. N.; BALUJA, C.; OTERO, M. L. Ozonation kinetics of glucosamine and N-acetyl glucosamine in aqueous medium. Ozone: Science and Engineering, Philadelphia, v. 17, n. 4, p. 463-467, 1995.

SANTOS, A. J. P. Avaliação da utilização de ozônio como método de beneficiamento de leite. Brasília: Universidade de Brasília, 2013. 45 p.

SHEELAMARY, M.; MUTHUKUMAR, M. Effectiveness of ozone in inactivating Listeria monocytogenes from milk samples. World Journal Young Researchers, Coimbatore, v. 1, n. 3, p. 40-44, 2011.

SILVA, S. B.; LUVIELMO, M. M.; GEYER, M. C.; PRÁ, I. Potencialidades do uso do ozônio no processamento de alimentos. Semina: Ciências Agrárias, Londrina, v. 32, n. 2, p. 659-682, 2011.

TIWARI, B. K.; MUTHUKUMARAPPAN, K. Ozone in fruit and vegetable processing. In: O'DONNELL, C. P.; TIWARI, B. K.; CULLEN, P. J.; RICE, R. G. Ozone in food processing. Oxford: Blackwell Publishing, 2012. p. 55-74.

VENEGAS, J. G.; HARRIS, R. S.; SIMON, B. A. A comprehensive equation for the pulmonary pressurevolume curve. American Physiological Society, Bethesda, v. 84, n. 1, p. 389-395, 1998. 
